\title{
RESEARCH AFFECT ECOLOGICAL-ECONOMIC FACTORS ON LAND USE OF AVIATION TRANSPORT
}

\author{
${ }^{I}$ Doctor of Economics, associate professor Iryna Novakovskaya \\ ${ }^{2}$ Liliia Skrypnyk \\ ${ }^{1}$ Kiev, Ukraine, National Aviation University \\ ${ }^{1}$ Head of the Department of Land Management and Cadastre \\ ${ }^{2}$ Kiev, Ukraine, Institute of Agroecology and Natural Resources of NAAS \\ ${ }^{2}$ Postgraduate student
}

DOI: https://doi.org/10.31435/rsglobal_ijite/30042019/6451

\begin{abstract}
ARTICLE INFO
Received 11 February 2019

Accepted 10 April 2019

Published 30 April 2019

\section{KEYWORDS}

ecological-economic factors, land use,

aviation transport

ABSTRACT

The article has been considered the influence of ecological and economic factors on ecologically safe, rational, economically efficient landing of aviation transport. The analysis of the harmful influence of aviation transport on the adjacent land use, as well as vital activity and health of people in the area of maximum, critical activity of the industry has been carried out. The methods of environmental management of the airport activity have been presented in order to prevent the occurrence and reduction of pollution of the environment by applying the Ecological Management System - the system of ecological management. Possible algorithm of ecological-economic estimation of design decisions in the context of interconnected operation of infrastructure of airline, aerodrome territory and adjacent land uses has been suggested.
\end{abstract}

Citation: Iryna Novakovskaya, Liliia Skrypnyk. (2019) Research Affect Ecological-Economic Factors on Land Use of Aviation Transport. International Journal of Innovative Technologies in Economy. 3(23). doi: 10.31435/rsglobal_ijite/30042019/6451

Copyright: (C) 2019 Iryna Novakovskaya, Liliia Skrypnyk. This is an open-access article distributed under the terms of the Creative Commons Attribution License (CC BY). The use, distribution or reproduction in other forums is permitted, provided the original author(s) or licensor are credited and that the original publication in this journal is cited, in accordance with accepted academic practice. No use, distribution or reproduction is permitted which does not comply with these terms.

Introduction. The analysis of the domestic development land use of aviation transport, as well as the research of foreign experience in this field, allowed to define the essence of the concept and to give a description of the term "ecologically safe land use of aviation transport". In our view, this concept should include a set of socio-economic, environmental and technical measures which are aimed at proper planning of airport infrastructure in coherence with adjacent territories, standardization of the level of pollutants, provision of the best possible internal and external ecological safety conditions for the community, integrity natural ecosystems and a high level of economic efficiency.

The ecological-economic system is an essential algorithm that should ensure the efficient land use of aviation transport and the industry as a whole. This system is considered as a holistic, which includes interconnected aircraft elements. However, despite this, the economic and environmental subsystems are characterized by various factors of influence.

The economic aspect of land use of aviation transport, which is part of the global ecological and economic system, is aimed at ensuring a high level of productivity of other industries and a powerful fixture for their growth. This activity improves the productivity of the global economy as a whole and includes the following factors:

- consolidation of tourism and trade ties;

- assistance to countries with a low socio-economic index (consolidation the position of the state in the world market, expanding access and strengthening the globalization of production);

- rapid development of the economic activity which the country specializes on; 
- increasing the level of economic efficiency and decreased delivery times for goods of different industries and functional purposes;

- increasing of the investment flows;

- development of innovative technologies by promoting effective networking between companies located in different parts of the globe.

Despite all the advantages that are the key to the rapid development of land use of aviation, it is impossible not to take into account its negative, sometimes catastrophic, impact on the ecological integrity of natural ecosystems. Dangerous substances that enter to the environment as a result of aviation transport activities are determined by the following processes:

1. The process of combustion of fuel leads to the formation of new chemical elements;

2. The combination of unburnt residues substances and compounds of atmospheric air, which interact with each other after undergoing a certain heat treatment, turn into emissions of combustion products;

3. Fuel pairs during the land operations;

4. Wastewater discharges and emissions during land operations and near the fuel and lubricant warehouse;

5. Aviation noise which is the result from the process of raising the sound level occurs as an effect of the operation of the aircraft engine in conjunction with aerodynamic characteristics of the aircraft.

The consequences of the dangerous influence of the aviation industry on health, normal human life and the integrity of the environment are caused by:

- change of physical, chemical and biological characteristics of the ecosystem;

- the course`s violation of natural biological processes;

- the formation of microbiological cleavage resistant even more toxic compounds, which contain carcinogenic and mutagenic qualities;

- soil contamination, its long-term adverse effects on animals, which is causing elimination in the intensive pollution zone.

Rational, ecologically safe, economically efficient land use of aviation transport is impossible without an integrated study of the peculiarities of the use and protection of this subcategory of land. Implementation of the ecological and economic assessment of restrictions on land use of aviation transport has become one of the priority tasks that will strengthen the international economic relations and expansion of airspace within the framework of development of cooperation with the EU. The problems of research analysis of the creation a unified general approach to the decision of the development issue of aviation land tenure have been fulfilled.

It is extremely essential to have a regulatory framework that would be adapted to EU rules and regulations in the field of aviation land use. Modern national legislation contains conflict rules, which is expressed even in the use of different terms to describe the same object - the land of aviation transport.

Research results. The development of the aviation industry is an integral part of the modern economic system, not only of the national level but also of the world scale. This is explained by the fact that today, in the context of the progressive international division of labor and the strengthening of economic and cultural ties, the indicated development for the national and world economy is becoming more and more significant.

The political forces of Ukraine, which is a member of the ICAO Council, are focusing their efforts in the aviation industry on the development of the airport network and strengthening the existing logistics and resource potential for the next 10 years by achieving a high level of passenger flow, which is a key indicator in achieving economic the effect in the field of aviation activities.

Ukraine's aviation transport strategy for the period up to 2030 reflects the basic theoretical and methodological principles of practical implementation and is based on the need for land-resource potential as a spatial basis for development. The main measures of the strategy are [8]:

1) state regulation of the legal regime for the use of aviation transport land, namely protection against changes in the purposeful use of land plots or illegal land development around the airports necessary for the development of airport infrastructure for the period of 20-30 years;

2) effective control over compliance with restrictions on high-rise buildings within a radius of $50 \mathrm{~km}$ around airports;

3) ensuring the growing tourist and business potential of the capital of Ukraine, through the development of the international airport "Kyiv" (Zhulyany) (lengthening and strengthening of the runway for the reception without restrictions of aircraft and 321/in 737-900), As a point-to-point 
airport, or through the design and construction of a new modern international airport in the Kiev region, and the development of access roads and high-quality ground communication with the airport by various types of public transport;

4) conducting an inventory of airports (airfields), as well as inventory of airfields in Ukraine for the purpose of conservation and use for low-cost transportation and/or general aviation;

5) travel to the country to ensure integrated construction prior to the reconstruction of the airport in order to ensure its need for abandoned vehicles access to vehicles and the population, points, in particular the development of modern transit infrastructure at Boryspil International Airport by reducing the share of net profit (income), which are expelled to the State budget;

6) the development and adoption of a package of airport laws as a matter of priority, similar to the EU, which should solve the critical aspects that hinder the development of airports in Ukraine and the entire aviation market.

For 2006-2017 years the market of aviation passenger transportations in Ukraine developed rather dynamically. In the last 11 years the volume of passenger transportations by Ukrainian airlines has grown almost in 6 times. Such indicators are the result of expansion of the route network and increase of the intensity of flights on the fixed directions simultaneously with renewal of the fleet of air strips. Also, significant passenger traffic has helped to increase safety measures and improve the quality of service.

According to predicted estimations of experts by 2030 the number of passengers of Boryspil International Airport will increase from $11 \mathrm{mln}$. Up to 30 million, 10 million of which-transfer (fig. 1). In turn, the total passenger traffic of all airports in Ukraine will reach the size-at least 42 million passengers. Some experts believe that in the next 10 years the number of passenger traffic of the central airport of Ukraine from 11 million will grow to 50 million passengers per year.

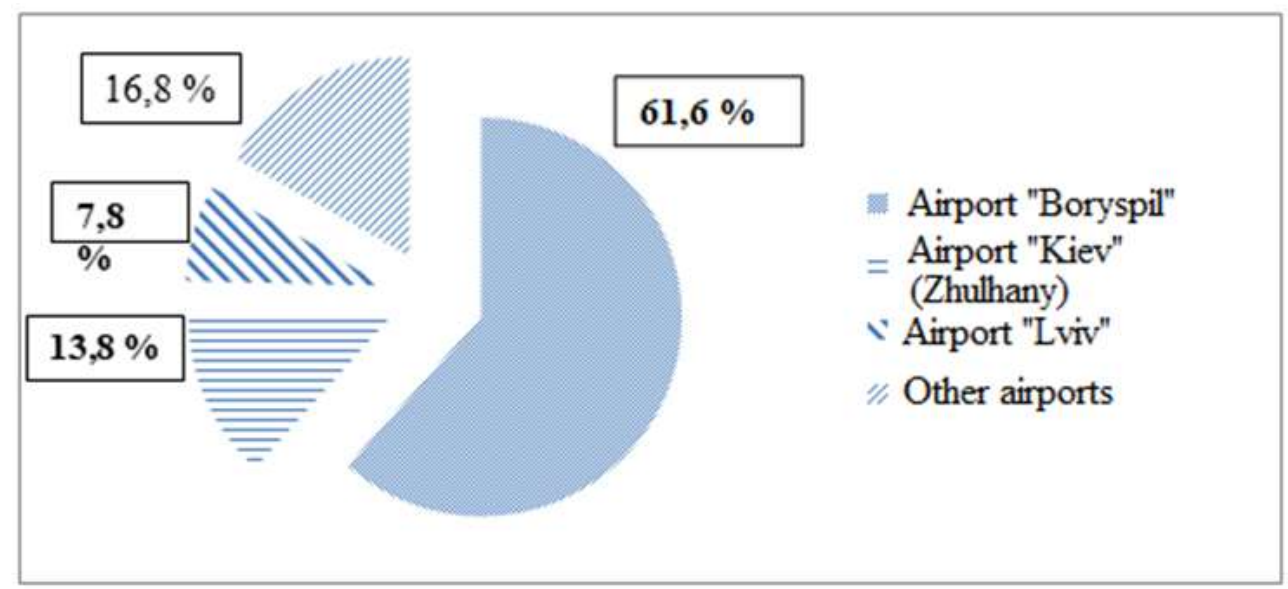

Fig. 1 percent of the level of passenger traffic on the network of airports in Ukraine by 2018 [8]

If we consider the level of passenger traffic as a percentage of specific airports, then $61.6 \%$ of the international Airport "Borispol", 13.8\%-International Airport "Kiev" (zhulyany), 7.8\%International Airport "Lviv" named after Daniel Galitsky, and 16.8\%-other airports. That is, from the whole network of airports in Ukraine, only 3 have the number of passenger traffic more than a million, MA "Borispol"-more than 10 million.

How can the forecasted level of passenger traffic in Ukraine increase up to 2030? The developers of the strategy are preparing for the signing of the Agreement on Common Aviation Space (SAP) with the European Union (EU), what they think will be the first step to increase the volume of passenger traffic in the airports of Ukraine. In general, the increase in passenger traffic is due to the following factors [3]:

- State of the economy;

- Level of social sphere of the country;

- Improvement, development of the network of airports, infrastructure and organization of adjacent land use;

- Internal and external tourism

- Entrepreneurial, commercial activity.

Despite the introduction and gradual implementation of the strategy, a serious problem remains, the environmental situation within the individual airports, as well as on adjacent land use and 
the ecosystem as a whole. Such conditions cause an extremely negative effect on human health and the integrity of the natural environment in the activity area of the branch.

Official statistics of British experts report that the aviation industry is causing emissions of harmful substances into the environment not only during passenger and freight transport, but also in various activities which are related to airport service in general.

Penetration of harmful substances into the soil, as a result of land operations (spills, waste water), leads to an active change in the chemical warehouse and soil structure. It is impossible not to notice that in the first place such influence affects the Humus horizon. That is, when the amount of hydrocarbons in it sharply deteriorate soil quality as a nutrient substrate for plants. Also soil contamination by hydrocarbons of oil and petroleum products leads to a sharp disturbance of soil microbiocenosis and is caused a long-term negative impact on animals, by elimination in the intensive zone of contamination. Sometimes aviation activity causes pollution of water bodies, large-scale forest fires.

If the impact of aviation noise on the health and condition of the population living in adjacent areas is considered, this factor will refer to the active processes of. At the moment, experts and researchers in the field of health regulation have found that the traumatic impact of aviation noise is stronger than other components of the negative factor.

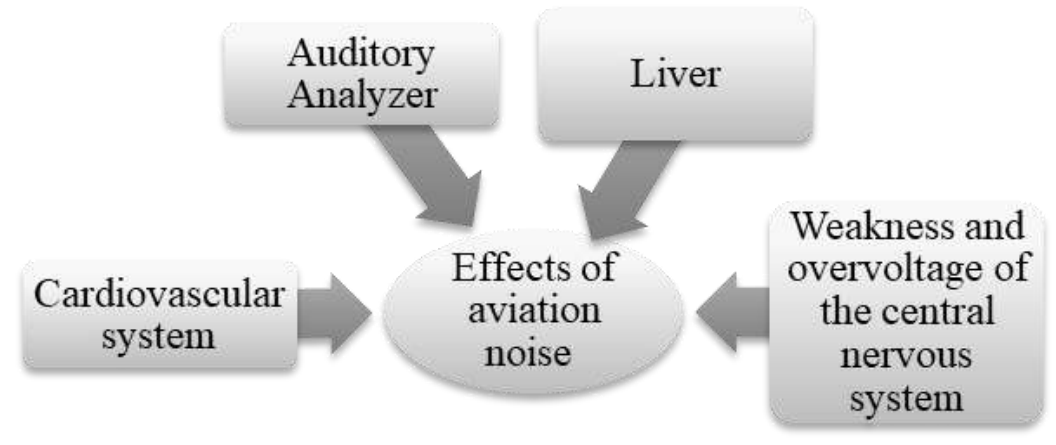

Fig. 2 Differentiation of systems of the human organism which the aviation noise most influences on [9]

The world study practice of the influence of aviation noise, allocates a scale with a risk factor influence 1.00 to 1.30 , which corresponds to a certain level of noise in the Dba, where there is a danger to the emergence of specific types of diseases (Fig. 3).

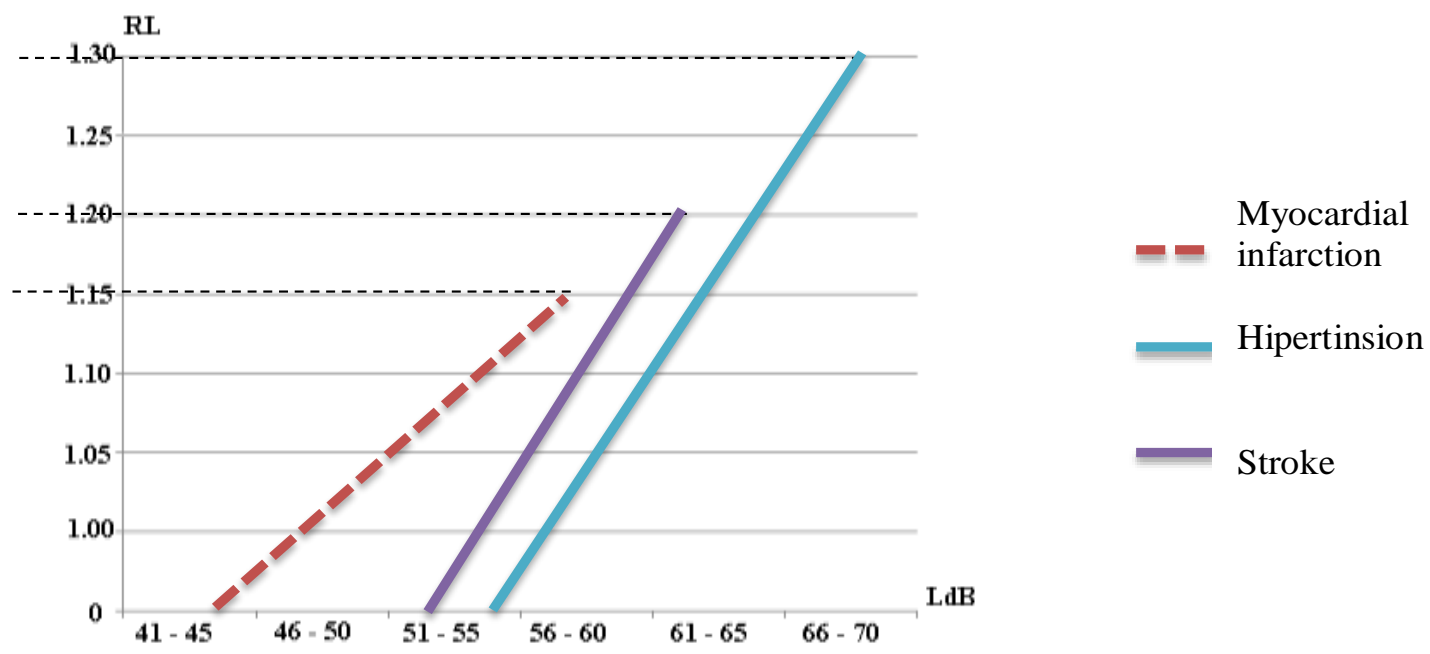

Fig. 3 Risk factors scale of occurrence of different diseases in the rookery from the level of aviation noise

*Formed by the author according to the report The Environment Aviation Federation, January 2016 «Aircraft noise and public health»

Emissions in the process of combustion of fuels and any other sources that lead to the release of hazardous chemicals into the atmosphere, the environment is another important aspect of the impact on the health of the population.

Residents of the airports adjacent to the airport are increasingly becoming victims of respiratory diseases or the appearance of malignant neoplasms. 
For an example, consider the level of morbidity of the population of Svyatoshinsky district, Kyiv, which is in its location, is located at a short distance from the International airport "Kyiv" (Zhulyany), with a population of 319,000 people. At the same time, some residential buildings are from the airport, at a distance of $5 \mathrm{~km}$, while the International requirements and the legislation of Ukraine regulate the radius of the aerodrome area in the size of $15 \mathrm{~km}$.

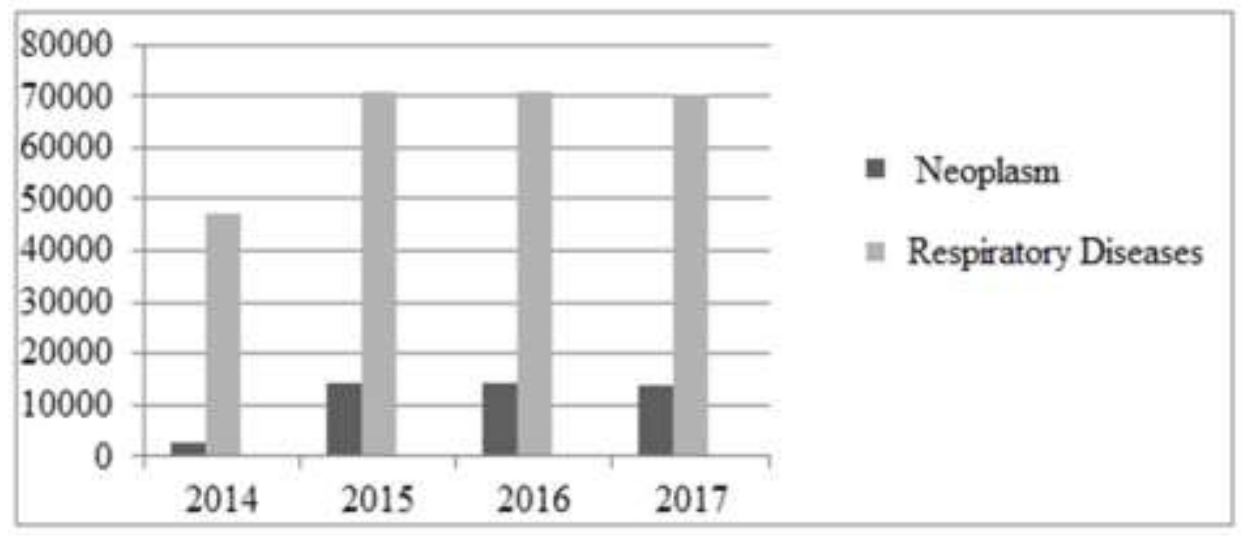

Fig. 4 The level of morbidity of the population of the Svyatoshinsky district of Kyiv, which is located within a radius of $5 \mathrm{~km}$ to the AI "Kyiv" (Zhulyany) in the period from 2014-2017

*Formulated by the author according to the statistical data of the Department of Health of Ukraine [9] Indicators of the morbidity rate of the Svyatoshinsky district population, which is located within a radius of $5 \mathrm{~km}$ to the AI "Kyiv" (Zhulyany) in the period from 2014-2017, have been calculated in accordance with the general indicators, which are determined by regions for every 10 thousand people (Figure 4). When the dynamics of fluctuations in the level of morbidity of the population has been determed, it was mandatory to take into account the fact that $60 \%$ complaints about the state of health have been associated with large-scale emissions of harmful chemical compounds into the atmosphere. As we see, the figures for 2014 differ significantly from the indicators in 2015, 2016, 2017, almost 2 times. That is, in 2015 there was a peak of the caused diseases, and already in 2016, 2017 the indicators have showed a decline, but not at all significant, comparing with the jump in the period from 2014 to 2015.

That is, one of the basic directions of the development network of Ukrainian airports is the effective use of methods for preventing and reducing emissions of hazardous pollutants.

The Ecological Management System (Ecological Management System - EMS) is considered to be the best way to manage the environment at all levels of corporate operations and decision making. Eco-efficient EMS work at airports, according to ICAO's researchers, can seriously help in monitoring and managing environmental issues.

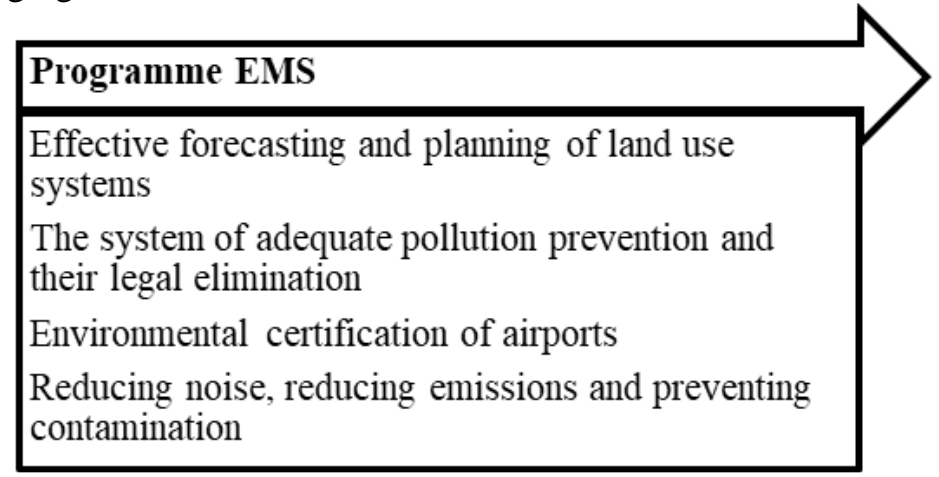

Fig. 5 Planning stages and practical application of the EMS system at airports

Specialists of the aviation organisation can significantly reduce the impact on the environment, in particular, the resource and land potential of the territory, if their activities will be aimed at the introduction and functioning of the environmental management system - EMS and forecasting, planning the land use process.

An example of world experience in making effective environmental environmental decisions inside and outside the airport is the creation of the "green zones". This concept includes: 
- production, operation of technologies and equipment for control and emissions reduction of harmful substances and greenhouse gases;

- preservation and replenishment of greenery on the territory of the airport and beyond;

- monitoring and forecasting of climate change;

- introduction of technological processes for energy and resource conservation and renewable energy [10].

The concept of "green zones" is widely used in the United States and European countries. They have developed a number of long-term programs and initiatives, according to which, by 2025, it is planned to develop new-generation planes with radically new technical and operational characteristics in accordance with the rules and requirements for the functioning of these zones.

The use of "green zones" for Ukrainian aviation organization is a necessary innovative solution for the conservation, protection of natural resources and the reduction of the negative impact on the ecosystem's integrity. An important tool for ensuring the functioning of these zones is the formation of an effective system of environmental management, the introduction and harmonization of environmental policy, taking into account the specific conditions of operation.

In recent years, the concept of "the problem of compatibility of airport infrastructure and land use in surrounding areas" is often used. Consideration of this issue is extremely essential and the concept of land-use planning is a consequence of the study of the environmental interconnection between airports and populated areas that are nearby.

Land-use features in areas around airports may be the reason for the establishment of restrictions on aircraft flights, and also affect the level of safety of flights. That is why, before planning and designing the airport, it is necessary to take appropriate measures to prevent the incompatible use of land plots.:

1) Ensuring mandatory certification of aviation objects for compliance with regulatory requirements.

2) Scientific substantiation of planning and forecasting of land use, taking into account the physical and geographical conditions of a particular region.

3) Conducting an assessment of the risks of birds collision with aircraft and the entry of wild animals into the aerodrome territory.

4) Compliance with and improvement of the planning concept of joint land use of the airport with the infrastructure, vegetation and land use of the adjacent territories to the airport.

5) Compliance with the rules for reducing the number of birds and wildlife around the airport.

Principles of environmental and economic assessment of design solutions in the context interconnected operation of the aeroport infrastructure at the aerodrome territory and adjacent land uses:

1. Ecological-economic effect as a result of interconnected functioning of the airport

infrastructure and land use in the aerodrome territory. The high level of economic incentives for land use in the aerodrome territory is the direction of the investment flows into the development of transport infrastructure around the airport, which will serve as the main intersections of the airport's flights. Such a balanced use of land will reduce fare, access and waiting time. formula [2]:

Net present value (NPV) of investment in transport infrastructure could be expressed as a

$$
N P V=-I+\sum_{t=1}^{T}\left(\Delta C S_{t}+\Delta P S_{t}\right)(1+i)^{-t}
$$

where, I - investment funds;

$\mathrm{T}$ - period of the life cycle of the project;

$\Delta \mathrm{CSt}$ - change in consumer surplus in year $\mathrm{t}$;

$\triangle \mathrm{PSt}-$ Change in producer surplus in year $\mathrm{t}$;

$\mathrm{i}$ - the discount rate.

2. Using of the Landside project main provisions for the providing balanced indicators of environmental and economic assessment of land use restrictions in the aerodrome territory

Another essential condition for ensuring the ecological and economic assessment of rational land use in the aerodrome territory is the launch of the Landside project.

The Landside project is an universally accepted global method for cost-effective planning of airport infrastructure and environmental safety. 
The project assesses the strategic, functional, operational, commercial, and environmentaleconomic aspects for the sustainable development of the airport and land-use objects outside its borders, in particular the restrictions - in the aerodrome territories.

3. Ecological and economic principles for assessing land use restrictions infrastructure of the airport (at the aerodrome territory)

In accordance with the provisions of the regulatory acts in the field of aviation, the airport operator is responsible for the state of the aerodrome territory and the conduct of any production, economic activities, as well as the activities of entities. That is why it is necessary to clearly define how the airport's activity will affect the ecological and economic condition of the aerodrome territory.

The non-economic aspects of land use in the aerodrome territory are considered due to changes in the cost of communications near the airport solely due to its direct impact on the environment within a radius of $15-50 \mathrm{~km}$. In the case of aviation noise, this aspect could be expressed as a formula [2]:

$$
\mathrm{DEC}_{\mathrm{LU}}=\mathrm{D}_{\mathrm{p}} * \mathrm{~V}_{\mathrm{p}} * \mathrm{r}_{\mathrm{lvp}} * \Delta \mathrm{F}_{\mathrm{n}}
$$

where, $\mathrm{D}_{\mathrm{p}}$ - density of properties within aerodrome territory which is affected by aviation noise over a certain period of time (unit of real estate / $\mathrm{km} 2$ ),

$\mathrm{V}_{\mathrm{p}}$ - the cost of a unit of real estate that is exposed to airborne noise over a certain period of time ( $€ /$ unit of real estate);

$\mathrm{r}_{\mathrm{lvp}}$ - the rate at which a unit of property loses its worth in connection with the increased impact of aviation noise over a certain period of time (\% / $1 \mathrm{~dB} /$ year);

$\Delta \mathrm{F}_{\mathrm{n}}$ - the limiting level of increase in aviation noise due to an increase in the number of air traffic over a certain period of time $(\mathrm{dB} /$ year $)$.

4. Ecological and economic principles of land use management in the aerodrome territory in the event of environmental and economic losses.

Environmental damage is a change in the quality state of the environment due to an increase in the maximum permissible level of hazardous, harmful substances.

This indicator is evaluated using the following values:

- additional costs of the airport operator and land users

- condition of the aerodrome territory due to changes in the environment;

- costs of returning the environment to the previous state;

- additional costs of the airport operator and land users

- the state of the aerodrome territory in the future due to the use of a part of scarce natural resources.

An effective ecological and economic precautionary mechanism in the case of land use restrictions in the territory arround the airport may be the pollution charge for the environment, which will be carried out by the airport operator. These funds will be used for the introduction of special measures for reducing or eliminating environmental and economic losses.

The number and level of payments may be determined on the basis of the maximum allowable emissions and discharges of each ingredient ( $t$ / year), which are set for the airport. The principles and amount of waste disposal in the environment are determined by the enterprises as the physical volume of waste depending on the class of toxicity.

Conclusions. Environmental and economic assessment should be carried out in relation to future projects, in order to reduce the risks of environmental instability of the territory and negative economic consequences that result in low efficiency in relation to the predictible results and indicators due to the activity of the relevant sphere.

The process of environmental and economic assessment of aviation land should be considered in the context of the interconnected functioning of the infrastructure of the airport and its adjoining territories. As experience of experts and specialists of international level shows, in this case, the assessment of the project decisions that relate the problem of environmentally sound land use and the needs of effective territorial development of the objects of the aviation industry will be conducted.

\section{REFERENCES}

1. Janić M. Air transport system analysis and modeling: Capacity, Quality ofServices and Economics [Text]/ Janić Milan. - Malaysia: Gordon and BreachScience Publishers, 2000. - 301p.https://www.tudelft.nl/en/ceg/aboutfaculty/departments/transport-planning/staff/personal-pages/janic-m/

2. Janic, M. (2013). Airport analysis, planning, and design: Demand, capacity, and congestion. New York, NY: Nova. 
3. ICAO. (2002). Airport planning manual, part 2: Land use and environmental control, 3rd ed. Montreal, Canada: Author.

4. Hirst M. The air transport system [Text] / Mike Hirst. - Cambridge: Woodhead Publishing Limited, 2008. - 341 p.

5. Novakovska, I. (2018). Economica zemlekorustyvannia: navch. posibnyk. Kyiv: Agrarnaya Nauka, 400 p. [in Ukrainian].

6. Iryna Novakovska, Liliia Skrypnyk (2018), "THE LAND USE OF AVIATION TRANSPORT IN UKRAINE: CONTEMPORARY STATUS AND DEVELOPMENT STRATEGY" ["Vykorystannya aviatsiynoho transportu v ukrayini: suchasnyy stan ta rozvytok stratehiyi"], Innovative Economics and Management Batumi, Georgia 2018, 65-72 pp.

7. Novakovska Iryna, Natalia Belousova, Ishchenko Natalia, Skrypnyk Liliia. Aviation industry of XXI century: development and necessity or serious threats for natural ecosystems [collective monograph]/ Kiev, Ukraine, Paris, France 2018, 226-238 pp.

8. Ukraine's aviation transport strategy for the period up to 2030 (2018): aviliable at: https://mtu.gov.ua/projects/166/

9. Department of Health. The main indicators of health of the population of Kyiv for the period from 2014 to 2017: aviliable at: https://health.kievcity.gov.ua/content/statystyka.html 